\title{
GROWTH AND YIELD OF WHEAT AS INFLUENCED BY MICRONUTRIENTS UNDER WATER DEFICIT CONDITION
}

\author{
M. A. Tithi ${ }^{1}$, M. A. Mannan ${ }^{1}$, M. A. R. Khan ${ }^{1}$ and M. M. Rahman ${ }^{2}$ \\ 1Department of Agronomy and 2Department of Soil Science \\ Bangabandhu Sheikh Mujibur Rahman Agricultural University, Bangladesh \\ Corresponding E-Mail: mannanbsmrau@yahoo.com
}

(Received: 25 April 2021, Accepted: 10 June 2021)

Keywords: Zn, Fe, application strategy, drought tolerance.

\begin{abstract}
Crop productivity is greatly affected by drought stress. In order to evaluate the effects of $\mathrm{Zn}$ and Fe micronutrients on growth and yield of wheat (Triticum aestivum L.) variety BARI Gom 29, a pot experiment was conducted at the Agronomy research field of Bangabandhu Sheikh Mujibur Rahman Agricultural University during November 2018 to March 2019. Two water regimes i.e. control (80\% of field capacity) and drought (40\% of field capacity) were maintained throughout the growing season. Micronutrients $\mathrm{Zn}$ and $\mathrm{Fe}$ viz. i) $\mathrm{ZnSO}_{4} \cdot 7 \mathrm{H}_{2} \mathrm{O}$ and $\mathrm{Fe}_{3} \mathrm{SO}_{4} \cdot 7 \mathrm{H}_{2} \mathrm{O}$ @22 $\mathrm{kgha}^{-1}$ were applied in soil before sowing; ii) $\mathrm{ZnSO}_{4} \cdot 7 \mathrm{H}_{2} \mathrm{O}$ solution and $\mathrm{Fe}_{3} \mathrm{SO}_{4} .7 \mathrm{H}_{2} \mathrm{O}$ solution @ $5 \%$ of each were applied as foliar spray at flowering stage following completely randomized design (CRD) with three replications. The results indicated that drought stress affected negatively wheat growth such as plant height, fresh weight of leaf, stem, root and total weight of plant as well as yield. $\mathrm{Zn}$ and Fe mitigate the drought effects in wheat which ultimately improve the growth and the yield. Among the micronutrients, $\mathrm{Fe}\left(\mathrm{Fe}_{3} \mathrm{SO}_{4} 7 \mathrm{H}_{2} \mathrm{O}\right)$ was found more effective when it was applied as foliar spray @ 5\% solution for increasing the growth and yield of wheat under water deficit stress condition.
\end{abstract}

\section{Introduction}

Wheat (Triticum aestivum L.) is economically one of the most important cereal crops in the world. Wheat, next to rice is the staple food of the people in Bangladesh. Less rainfall is the main constraint for wheat production in the arid/semi-arid regions, and it is reducing $50 \%$ crop yield (Wang et al., 2003). Climate change is associated with global warming that affects climatic variability. Drought is the environmental stress that negatively affects the growth, development and productivity of a crop (Kamal et al., 2010).

Various techniques are being used to protect plants from the adverse effects of abiotic stresses like drought, which include exogenous supplementations of silicon, nitric oxide, growthpromoting hormones, enzymes, and nutrient management (Saxena and Shekhawat, 2013). Among the remedies for abiotic stress, nutrient regulations or management are considered as the cost effective and ecofriendly techniques (Tripathi et al., 2017). In addition, studies also showed that an exogenous supply of nutrients plays a crucial role in the enhancement of plant tolerance against various abiotic stresses. Some nutrients such as calcium (Ca), magnesium (Mg), sulfur $(\mathrm{S})$, zinc $(\mathrm{Zn})$, and iron $(\mathrm{Fe})$ have shown significant results when they are examined under salinity, drought, and heavy-metal stresses (Nazar et al., 2012). Currently, the application of Fe as a nutrient supplement and its role in imparting tolerance to plants against abiotic stresses are 
gaining attention as an area of research. Tabatabai et al. (2015) reported that zinc sulfate played a more important role in stomata regulation and ion balance in plant systems to reduce the tension of drought. Considering above facts, the objectives of the present study were to investigate the effectiveness of zinc $(\mathrm{Zn})$ and iron $(\mathrm{Fe})$ micronutrients in reducing the adverse effects of drought stress in wheat in relation to growth and yield, and to identify the effective application method of zinc $(\mathrm{Zn})$ and iron $(\mathrm{Fe})$ for improving the drought tolerance potential of wheat.

\section{Materials and Methods}

Site and soil description: A pot experiment was conducted under semi-controlled environment (inside screen house) at Department of Agronomy, Bangabandhu Sheikh Mujibur Rahman Agricultural University (BSMRAU), Gazipur, Bangladesh during November 2018 to March 2019. The experimental site is in the center of Madhupur Tract $\left(24.09^{\circ} \mathrm{N}\right.$ latitude and $90.26^{\circ} \mathrm{E}$ longitude) at $8.4 \mathrm{~m}$ above the sea level. Plastic pots $(30 \mathrm{~cm}$ length and $24 \mathrm{~cm}$ diameter) were used in the experiment which was filled with soil, holds about 28\% moisture at field capacity (FC). The soil of the pot was fertilized uniformly with $0.9,0.8$ and $0.8 \mathrm{~g}$ urea, triple super phosphate and muriate of potash corresponding to 160-150-150 kg urea, triple super phosphate and muriate of potash per hectare, respectively (BARC,2012). The experimental soil was sandy loam with $\mathrm{pH} 6.93$, soil organic carbon $0.61 \%$, total $\mathrm{N} 0.070 \%$, available P $0.06 \mathrm{mg}$ $100 \mathrm{~g}^{-1}$, exchangeable $\mathrm{K} 0.79 \mathrm{cmol}_{\mathrm{c}} \mathrm{kg}^{-1} \mathrm{dry}$ soil, available S $10.00 \mu \mathrm{g} \mathrm{g}-1$, CEC $13.05 \mathrm{cmol}_{\mathrm{c}}$ $\mathrm{kg}^{-1}$ dry soil and EC $0.04 \mathrm{dSm}^{-1}$. Air temperature, relative humidity and rainfall in the period of experimentation are presented in Table 1.

Table 1. Air temperature, relative humidity and rainfall in the period of experimentation

\begin{tabular}{lccccc}
\hline Month & \multicolumn{3}{c}{ Air temperature $\left(^{\circ} \mathrm{C}\right)$} & Relative & Total \\
& Maximum & Minimum & Average & humidity (\%) & rainfall(mm) \\
\hline November, 2018 & 29.22 & 17.22 & 23.22 & 86.73 & 71.10 \\
December, 2018 & 25.50 & 13.10 & 19.30 & 86.65 & 21.69 \\
January, 2019 & 26.61 & 11.61 & 19.22 & 85.42 & 0.00 \\
February, 2019 & 27.82 & 14.34 & 20.26 & 85.36 & 46.10 \\
March, 2019 & 27.88 & 14.43 & 24.5 & 85.27 & 51.32 \\
\hline
\end{tabular}

Source; Department of Agricultural Engineering, BSMRAU

(http://bsmrau.edu.bd/age/weather-data/)

Treatments and experimental design: The experiment was designed at Completely Randomized Design (CRD) with three replications. Ten seeds of BARI Gom 29 were sown in each pot and light irrigation was given by using the watering can to ensure uniform germination. After germination thinning were done remaining 3 healthy seedlings in each pot. The treatment combinations were: $\mathrm{C}=$ Control ( $80 \%$ of field capacity), $\mathrm{D}_{1}=$ Drought ( $40 \%$ of field capacity), $\mathrm{D}_{2}=$ Drought $\quad \mathrm{ZnSO}_{4} \cdot 7 \mathrm{H}_{2} \mathrm{O} @ 22 \mathrm{kgha}^{-1}\left(11 \mathrm{mgkg}^{-1}\right.$ soil), $\mathrm{D}_{3}=$ Drought+ $\mathrm{Fe}_{3} \mathrm{SO}_{4} \cdot 7 \mathrm{H}_{2} \mathrm{O}$ $@ 22 \mathrm{kgha}^{-1}$ (11 mgkg-1 soil), $\mathrm{D}_{4}=$ Drought+ $\mathrm{ZnSO}_{4} \cdot 7 \mathrm{H}_{2} \mathrm{O}+\mathrm{Fe}_{3} \mathrm{SO}_{4} \cdot 7 \mathrm{H}_{2} \mathrm{O} @ 22 \mathrm{kgha}^{-1}$ (11 $\mathrm{mgkg}^{-1}$ soil)of both, $\mathrm{D}_{5}=$ Drought $+\mathrm{ZnSO}_{4} \cdot 7 \mathrm{H}_{2} \mathrm{O} @ 5 \%\left(5 \mathrm{~g} 100 \mathrm{~mL}^{-1}\right.$ water $)$ as foliar spray, $\mathrm{D}_{6}=$ Drought+ $\mathrm{Fe}_{3} \mathrm{SO}_{4} \cdot 7 \mathrm{H}_{2} \mathrm{O} @ 5 \%$ (5 g100 mL-1 water)as foliar spray, $\mathrm{D}_{7}=$ Drought+ $\mathrm{ZnSO}_{4} \cdot 7 \mathrm{H}_{2} \mathrm{O}+\mathrm{Fe}_{3} \mathrm{SO}_{4} \cdot 7 \mathrm{H}_{2} \mathrm{O} @ 5 \%\left(5 \mathrm{~g} 100 \mathrm{~mL}^{-1}\right.$ water $)$ of both foliar spray. $\mathrm{ZnSO}_{4} \cdot 7 \mathrm{H}_{2} \mathrm{O}$ and $\mathrm{Fe}_{3} \mathrm{SO}_{4} \cdot 7 \mathrm{H}_{2} \mathrm{O}$ were applied in soil before sowing and solutions treatments were applied as foliar spray at flowering stage. Moisture level in pot soil was measured daily using portable digital moisture meter (POGO Soil Sensor II, Stevens, USA) and required amount of water was added daily to reach $80 \%$ of field capacity and $40 \%$ of field capacity for control and drought treatments, respectively. 
Data recorded: Growth parameters like plant height, fresh weight of leaf, stem, root and total weight of plant were recorded at 15 and 30 days after flowering. Yield and yield contributing parameters were recorded at maturity after harvest.

Data analysis: The recorded data were statistically analyzed by "Crop Stat 7.2" software to examine the significant variation of the results due to different treatments. The treatment means were compared by Least Significant Difference (LSD) test at 5\% level of significance (Gomez and Gomez, 1984). Microsoft EXCEL 2013 software program was used wherever appropriate to perform statistical analysis.

\section{Results and Discussion}

\section{Growth attributes}

Plant height of wheat variety BARIGom 29 varied appreciably under drought stress as presented in Figure 1. Though plant height is genetically controlled, drought stress also played a significant role in its regulation. Plant height showed an increasing trend but drought stress significantly reduced the rate of increase in plant height of the wheat variety. At 15 days after flowering, in control condition the plant height was $58.72 \mathrm{~cm}$ and in drought condition the plant height was $49.55 \mathrm{~cm}$. Application of $\mathrm{Zn}$ and Fe micronutrients increased the plant height under drought stress and the highest plant height $(56.26 \mathrm{~cm})$ was recorded when $\mathrm{Fe}_{3} \mathrm{SO}_{4} .7 \mathrm{H}_{2} \mathrm{O}$ was applied $@ 5 \%$ solution as foliar spray followed by $\mathrm{Fe}_{3} \mathrm{SO}_{4} .7 \mathrm{H}_{2} \mathrm{O} @ 22 \mathrm{kgha}^{-1}(54.27 \mathrm{~cm}), \mathrm{ZnSO}_{4} \cdot 7 \mathrm{H}_{2} \mathrm{O}$ @ $22 \mathrm{kgha}^{-1}(53.40 \mathrm{~cm}), \mathrm{ZnSO}_{4} \cdot 7 \mathrm{H}_{2} \mathrm{O} @ 5 \%$

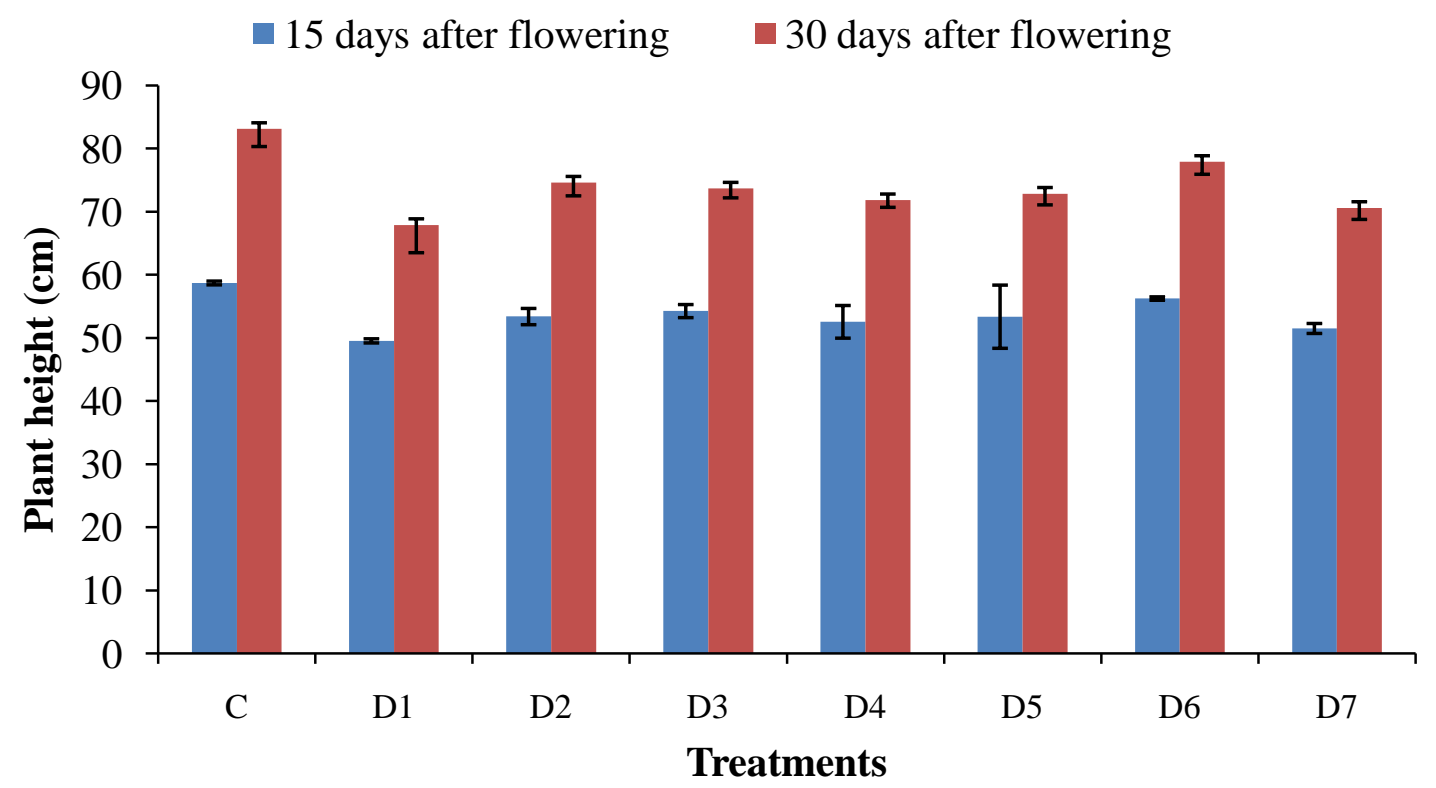

$\mathrm{C}=$ Control, $\mathrm{D}_{1}=$ Drought, $\mathrm{D}_{2}=$ Drought $+\mathrm{ZnSO}_{4} \cdot 7 \mathrm{H}_{2} \mathrm{O} @ 22 \mathrm{kgha}^{-1}, \mathrm{D} 3=$ Drought $+\mathrm{Fe}_{3} \mathrm{SO}_{4} \cdot 7 \mathrm{H}_{2} \mathrm{O} @ 22 \mathrm{kgha}^{-1}$, $\mathrm{D} 4=$ Drought $+\mathrm{ZnSO}_{4} \cdot 7 \mathrm{H}_{2} \mathrm{O}+\mathrm{Fe}_{3} \mathrm{SO}_{4} .7 \mathrm{H}_{2} \mathrm{O} @ 22 \mathrm{kgha}^{-1}$ of both, D5=Drought+ $\mathrm{ZnSO}_{4} .7 \mathrm{H}_{2} \mathrm{O} @ 5 \%$ solution as foliar spray, D6= Drought+ $\mathrm{Fe}_{3} \mathrm{SO}_{4 .} 7 \mathrm{H}_{2} \mathrm{O} @ 5 \%$ solution as foliar spray, D7= Drought+ $\mathrm{ZnSO}_{4} .7 \mathrm{H}_{2} \mathrm{O}+$ $\mathrm{Fe}_{3} \mathrm{SO}_{4} .7 \mathrm{H}_{2} \mathrm{O} @ 5 \%$ solution of both as foliar spray

Fig. 1. Effect of $\mathrm{Zn}$ and $\mathrm{Fe}$ on plant height of wheat under drought stress at 15 and 30 days after flowering.

Bars indicate $( \pm \mathrm{SE})$. 
solution as foliar spray $(53.38 \mathrm{~cm}), \mathrm{ZnSO}_{4} \cdot 7 \mathrm{H}_{2} \mathrm{O}+\mathrm{Fe}_{3} \mathrm{SO}_{4 .} 7 \mathrm{H}_{2} \mathrm{O} @ 22 \mathrm{kgha}^{-1}$ of both $(52.27$ $\mathrm{cm}$ ) and the lowest was recorded in $\mathrm{ZnSO}_{4} \cdot 7 \mathrm{H}_{2} \mathrm{O}+\mathrm{Fe}_{3} \mathrm{SO}_{4} .7 \mathrm{H}_{2} \mathrm{O} @ 5 \%$ solution of both as foliar spray $(51.51 \mathrm{~cm})$. On the other hand, at 30 days after flowering, in control condition the plant height was $83.11 \mathrm{~cm}$ and in drought condition it was $67.89 \mathrm{~cm}$. Under drought condition the highest plant height $(77.89 \mathrm{~cm})$ was recorded when $\mathrm{Fe}_{3} \mathrm{SO}_{4} .7 \mathrm{H}_{2} \mathrm{O}$ was applied $@ 5 \%$ solution as foliar spray and the lowest was recorded in $70.59 \mathrm{~cm}$ when $\mathrm{ZnSO}_{4} .7 \mathrm{H}_{2} \mathrm{O}+$ $\mathrm{Fe}_{3} \mathrm{SO}_{4} .7 \mathrm{H}_{2} \mathrm{O}$ was applied @ 5\% solution of both as foliar spray. The decrease in plant height might be due to decrease in relative turgidity and dehydration of protoplasm which in associated with the loss of turgor and reduce expansion of cell and cell division (Arnon, 1972). Soil application and foliar spray of $\mathrm{Fe}$ alone or in combination with other micronutrients increase plant height of wheat reported by Abbas et al. (2009). Monjezi et al. (2013) was found that drought stress on wheat reduced the plant height, but with $\mathrm{Zn}$ application significantly increased the plant height. These findings agreed with those of Bayoumi et al. (2008) in wheat, Manivannan et al. (2007) in sunflower those reported reduction in plant height under drought stress and found positive effects of micronutrients on plant height.

Drought stress exerted significant effect on leaf fresh weight of BARI Gom 29 as shown in Table 2. Leaf fresh weight showed an increasing trend but drought stress appreciably reduced the rate of increase in leaf fresh weight of the wheat variety. It was observed that in control condition the leaf fresh weightplant ${ }^{-1}$ was $3.57 \mathrm{~g}$ and in drought condition it was $2.15 \mathrm{gat} 15$ days after flowering. $\mathrm{Zn}$ and $\mathrm{Fe}$ micronutrients tended to reduce the adverse effect of drought stress in relation to leaf fresh weight and the highest leaf fresh weight $(3.40 \mathrm{~g})$ was recorded when $\mathrm{Fe}_{3} \mathrm{SO}_{4} .7 \mathrm{H}_{2} \mathrm{O}$ was applied @ $9 \%$ solution as foliar spray followed by $\mathrm{ZnSO}_{4} \cdot 7 \mathrm{H}_{2} \mathrm{O} @ 5 \%$ solution as foliar spray $(2.58 \mathrm{~g}), \mathrm{ZnSO}_{4} \cdot 7 \mathrm{H}_{2} \mathrm{O}+\mathrm{Fe}_{3} \mathrm{SO}_{4} .7 \mathrm{H}_{2} \mathrm{O} @ 22 \mathrm{kgha}^{-1}$ of both $(2.57 \mathrm{~g})$, $\mathrm{ZnSO}_{4} \cdot 7 \mathrm{H}_{2} \mathrm{O} @ 22 \mathrm{kgha}^{-1}(2.42 \mathrm{~g}), \mathrm{Fe}_{3} \mathrm{SO}_{4} .7 \mathrm{H}_{2} \mathrm{O} @ 22 \mathrm{kgha}^{-1}(2.40 \mathrm{~g})$ and the lowest was recorded in $\mathrm{Fe}_{3} \mathrm{SO}_{4} .7 \mathrm{H}_{2} \mathrm{O} @ 5 \%$ solution of both as foliar spray $(2.37 \mathrm{~g})$. Consequently, at 30 days after flowering, in control condition the leaf fresh weightplant ${ }^{-1}$ was $3.98 \mathrm{~g}$ and in drought condition the leaf fresh weightplant ${ }^{-1}$ was $2.22 \mathrm{~g}$. The highest leaf fresh weight plant ${ }^{-1}(3.40 \mathrm{~g})$ was recorded in $\mathrm{Fe}_{3} \mathrm{SO}_{4} 7 \mathrm{H}_{2} \mathrm{O} @ 5 \%$ solution as foliar spray treatment followed by $\mathrm{Fe}_{3} \mathrm{SO}_{4} .7 \mathrm{H}_{2} \mathrm{O} @ 22 \mathrm{kgha}^{-1}(2.72 \mathrm{~g}), \mathrm{ZnSO}_{4} \cdot 7 \mathrm{H}_{2} \mathrm{O} @ 5 \%$ solution as foliar spray $(2.71 \mathrm{~g})$, $\mathrm{ZnSO}_{4} .7 \mathrm{H}_{2} \mathrm{O}+\mathrm{Fe}_{3} \mathrm{SO}_{4} .7 \mathrm{H}_{2} \mathrm{O} @ 22 \mathrm{kgha}^{-1}$ of both $(2.64 \mathrm{~g}), \mathrm{ZnSO}_{4} .7 \mathrm{H}_{2} \mathrm{O} @ 22 \mathrm{kgha}^{-1}(2.50 \mathrm{~g})$ and the lowest was recorded in $\mathrm{Fe}_{3} \mathrm{SO}_{4} .7 \mathrm{H}_{2} \mathrm{O} @ 5 \%$ solution of both as foliar spray $(2.57 \mathrm{~g}$ ) under drought condition. It was found that drought stress reduced the leaf fresh weightplant ${ }^{-1}$ but application of $\mathrm{Zn}$ and $\mathrm{Fe}$ increases the leaf fresh weight in all of the cases. Reduction in leaf fresh weight might be due to loss of leaf turgidity under drought (Salsinha et al., 2020), which was maintained at a satisfactory level when micronutrients were applied in drought condition in our study.

Stem fresh weight of wheat variety BARIGom 29 showed a great variation due to drought stress as indicated in Table 2. The stem fresh weightplant ${ }^{-1}$ was $5.43 \mathrm{~g}$ in control condition and in drought condition it was $3.34 \mathrm{~g}$ at 15 days after flowering. Both $\mathrm{Zn}$ and $\mathrm{Fe}$ had positive impact under drought stress on stem fresh weight and the highest value of stem freshweightplant ${ }^{-1}$ (4.44 g) was recorded in $\mathrm{Fe}_{3} \mathrm{SO}_{4} .7 \mathrm{H}_{2} \mathrm{O} @ 5 \%$ solution as foliar spray treatment followed by $\mathrm{ZnSO}_{4} \cdot 7 \mathrm{H}_{2} \mathrm{O}+\mathrm{Fe}_{3} \mathrm{SO}_{4} .7 \mathrm{H}_{2} \mathrm{O} @ 22 \mathrm{kgha}^{-1}$ of both $(4.14 \mathrm{~g}), \mathrm{ZnSO}_{4} \cdot 7 \mathrm{H}_{2} \mathrm{O} @ 5 \%$ solution as foliar spray (3.93g), $\mathrm{ZnSO}_{4} .7 \mathrm{H}_{2} \mathrm{O} @ 22 \mathrm{kgha}^{-1}(3.79 \mathrm{~g}), \mathrm{Fe}_{3} \mathrm{SO}_{4} .7 \mathrm{H}_{2} \mathrm{O} @ 22 \mathrm{kgha}^{-1}(3.69 \mathrm{~g})$ and the lowest was recorded in $\mathrm{ZnSO}_{4} .7 \mathrm{H}_{2} \mathrm{O}+\mathrm{Fe}_{3} \mathrm{SO}_{4} .7 \mathrm{H}_{2} \mathrm{O} @ 5 \%$ solution of both as foliar spray $(3.45 \mathrm{~g})$. Thus, at 30 days after flowering, the stem fresh weight plant ${ }^{-1}$ was $10.38 \mathrm{~g}$ in control condition and in drought condition it was 6.01g. Application of $\mathrm{Zn}$ and $\mathrm{Fe}$ improved the ability of wheat plant to tolerate drought stress by maintaining greater stem fresh weight and the highest stem fresh weightplant ${ }^{-1}(7.03 \mathrm{~g})$ was recorded in $\mathrm{Fe}_{3} \mathrm{SO}_{4 .} 7 \mathrm{H}_{2} \mathrm{O} @ 5 \%$ solution as foliar 
spray treatment followed by $\mathrm{ZnSO}_{4} \cdot 7 \mathrm{H}_{2} \mathrm{O} @ 22 \mathrm{kgha}^{-1}(6.90 \mathrm{~g}), \mathrm{ZnSO}_{4} \cdot 7 \mathrm{H}_{2} \mathrm{O}+\mathrm{Fe}_{3} \mathrm{SO}_{4} .7 \mathrm{H}_{2} \mathrm{O}$ @ $22 \mathrm{kgha}^{-1}$ of both (6.40g), $\mathrm{Fe}_{3} \mathrm{SO}_{4} .7 \mathrm{H}_{2} \mathrm{O} @ 22 \mathrm{kgha}^{-1}(6.37 \mathrm{~g}), \mathrm{ZnSO}_{4} \cdot 7 \mathrm{H}_{2} \mathrm{O} @ 5 \%$ solution as foliar spray (6.27g) and the lowest was recorded in $\mathrm{ZnSO}_{4} \cdot 7 \mathrm{H}_{2} \mathrm{O}+\mathrm{Fe}_{3} \mathrm{SO}_{4} .7 \mathrm{H}_{2} \mathrm{O} @ 5 \%$ solution of both as foliar spray $(6.21 \mathrm{~g})$. Though drought stress adversely affected stem fresh weight in wheat, but the application of micronutrients established a positive effect with stem fresh weight in most of the cases.

Root fresh weight of the wheat variety BARI Gom 29 varied appreciably under drought stress as presented in Table 2. Application of $\mathrm{Zn}$ and Fe showed a better performance at 15 days after flowering in terms of root fresh weightplant ${ }^{-1}$ and in control condition it was recorded $1.18 \mathrm{~g}$, whereas in drought condition it was found 0.56 gplant $^{-1}$. After $\mathrm{Zn}$ and Fe application in drought condition, the highest root fresh weightplant ${ }^{-1}(0.81 \mathrm{~g})$ was recorded in $\mathrm{Fe}_{3} \mathrm{SO}_{4} .7 \mathrm{H}_{2} \mathrm{O} @ 5 \%$ solution as foliar spray treatment followed by $\mathrm{ZnSO}_{4} \cdot 7 \mathrm{H}_{2} \mathrm{O}+\mathrm{Fe}_{3} \mathrm{SO}_{4} .7 \mathrm{H}_{2} \mathrm{O} @ 22 \mathrm{kgha}^{-1}$ of both $(0.74 \mathrm{~g}), \mathrm{Fe}_{3} \mathrm{SO}_{4} .7 \mathrm{H}_{2} \mathrm{O} @ 22 \mathrm{kgha}^{-1}(0.68 \mathrm{~g}), \mathrm{ZnSO}_{4} \cdot 7 \mathrm{H}_{2} \mathrm{O} @ 5 \%$ solution as foliar spray $(0.68 \mathrm{~g}), \mathrm{ZnSO}_{4} \cdot 7 \mathrm{H}_{2} \mathrm{O} @ 22 \mathrm{kgha}^{-1}(0.62 \mathrm{~g})$ and the lowest was recorded in $\mathrm{ZnSO}_{4} .7 \mathrm{H}_{2} \mathrm{O}+$ $\mathrm{Fe}_{3} \mathrm{SO}_{4} .7 \mathrm{H}_{2} \mathrm{O} @ 5 \%$ solution of both as foliar spray $(0.61 \mathrm{~g})$. Likewise, at 30 days after flowering, the positive influence of $\mathrm{Zn}$ and $\mathrm{Fe}$ on root fresh weight plant $^{-1}$ was found and in control condition it was $1.83 \mathrm{~g}$, whereas in drought condition it was $0.89 \mathrm{~g}$. The highest root fresh weightplant ${ }^{-1}(1.70 \mathrm{~g})$ was recorded in $\mathrm{Fe}_{3} \mathrm{SO}_{4} .7 \mathrm{H}_{2} \mathrm{O} @ 5 \%$ solution as foliar spray treatment followed by $\mathrm{ZnSO}_{4} .7 \mathrm{H}_{2} \mathrm{O} @ 5 \%$ solution as foliar spray $(1.38 \mathrm{~g}), \mathrm{Fe}_{3} \mathrm{SO}_{4} .7 \mathrm{H}_{2} \mathrm{O} @ 22$ $\mathrm{kgha}^{-1}(1.32 \mathrm{~g}), \mathrm{ZnSO}_{4} \cdot 7 \mathrm{H}_{2} \mathrm{O}+\mathrm{Fe}_{3} \mathrm{SO}_{4} .7 \mathrm{H}_{2} \mathrm{O} @ 22 \mathrm{~kg} \mathrm{ha}{ }^{-1}$ of both$(1.31 \mathrm{~g}), \mathrm{ZnSO}_{4} \cdot 7 \mathrm{H}_{2} \mathrm{O} @ 22$ $\mathrm{kgha}^{-1}(1.22 \mathrm{~g})$ and the lowest was recorded in $\mathrm{ZnSO}_{4} \cdot 7 \mathrm{H}_{2} \mathrm{O}+\mathrm{Fe}_{3} \mathrm{SO}_{4} .7 \mathrm{H}_{2} \mathrm{O} @ 5 \%$ solution of both as foliar spray $(1.13 \mathrm{~g})$ under drought condition. It was reported by Morizet et al. (1983) that root weight increased while shoot weight decreased with the application of water deficit stress. This result is in agreement with the findings reported by Shahbaz et al. (2012) who showed a marked reduction of root fresh weight when wheat varieties were grown under drought stress for 7 weeks.

Table 2. Effect of $\mathrm{Zn}$ and Fe micronutrients on leaf fresh weight, stem fresh weight, root fresh weight, and total fresh weight of wheat under drought stress at 15 and 30 days after flowering (DAF)

\begin{tabular}{ccccccccc}
\hline \multirow{2}{*}{$\begin{array}{c}\text { Treat } \\
\text { ments }\end{array}$} & \multicolumn{2}{c}{$\begin{array}{c}\text { Leaf fresh weight } \\
\text { (gplant }^{-1} \text { ) }\end{array}$} & \multicolumn{2}{c}{$\begin{array}{c}\text { Stem fresh weight } \\
\text { (gplant }^{-1} \text { ) }\end{array}$} & \multicolumn{2}{c}{$\begin{array}{c}\text { Root fresh weight } \\
\text { (gplant }^{-1} \text { ) }\end{array}$} & \multicolumn{2}{c}{$\begin{array}{c}\text { Total fresh weight } \\
\text { (gplant }^{-1} \text { ) }\end{array}$} \\
\cline { 2 - 8 } & 15 DAF & 30 DAF & 15 DAF & 30 DAF & 15 DAF & 30 DAF & 15 DAF & 30 DAF \\
\hline C & 3.57 & 3.98 & 5.43 & 10.38 & 1.18 & 1.83 & 10.18 & 16.19 \\
$\mathrm{D}_{1}$ & 2.15 & 2.22 & 3.34 & 6.01 & 0.56 & 0.89 & 6.02 & 9.12 \\
$\mathrm{D}_{2}$ & 2.42 & 2.57 & 3.79 & 6.90 & 0.62 & 1.22 & 6.83 & 10.69 \\
$\mathrm{D}_{3}$ & 2.40 & 2.72 & 3.69 & 6.37 & 0.68 & 1.32 & 6.77 & 10.41 \\
$\mathrm{D}_{4}$ & 2.57 & 2.64 & 4.14 & 6.40 & 0.74 & 1.31 & 7.45 & 10.25 \\
$\mathrm{D}_{5}$ & 2.58 & 2.71 & 3.93 & 6.27 & 0.68 & 1.38 & 7.19 & 10.29 \\
$\mathrm{D}_{6}$ & 3.30 & 3.40 & 4.44 & 7.03 & 0.81 & 1.70 & 8.55 & 12.13 \\
$\mathrm{D}_{7}$ & 2.37 & 2.56 & 3.45 & 6.21 & 0.61 & 1.13 & 6.43 & 9.90 \\
\hline $\mathrm{LSD}(5 \%)$ & 0.9 & 0.97 & 1.13 & 3.45 & 0.19 & 0.42 & 2.07 & 3.89 \\
$\mathrm{CV}(\%)$ & 36 & 19.5 & 17.5 & 31.5 & 15.9 & 23.2 & 16.2 & 25.4 \\
\hline
\end{tabular}

$\mathrm{C}=$ Control, $\mathrm{D}_{1}=$ Drought, $\mathrm{D}_{2}=$ Drought $+\mathrm{ZnSO}_{4} \cdot 7 \mathrm{H}_{2} \mathrm{O} @ 22 \mathrm{kgha}^{-1}, \mathrm{D}_{3}=$ Drought $+\mathrm{Fe}_{3} \mathrm{SO}_{4} \cdot 7 \mathrm{H}_{2} \mathrm{O} @ 22 \mathrm{kgha}^{-1}$, $\mathrm{D}_{4}=$ Drought $+\mathrm{ZnSO}_{4} \cdot 7 \mathrm{H}_{2} \mathrm{O}+\mathrm{Fe}_{3} \mathrm{SO}_{4} .7 \mathrm{H}_{2} \mathrm{O} @ 22 \mathrm{kgha}^{-1}$ of both, $\mathrm{D}_{5}=$ Drought $+\mathrm{ZnSO}_{4} \cdot 7 \mathrm{H}_{2} \mathrm{O} @ 5 \%$ solution as foliar spray, $\mathrm{D}_{6}=$ Drought $+\mathrm{Fe}_{3} \mathrm{SO}_{4} .7 \mathrm{H}_{2} \mathrm{O} @ 5 \%$ solution as foliar spray, $\mathrm{D}_{7}=$ Drought $+\mathrm{ZnSO}_{4} .7 \mathrm{H}_{2} \mathrm{O}+$ $\mathrm{Fe}_{3} \mathrm{SO}_{4} .7 \mathrm{H}_{2} \mathrm{O} @ 5 \%$ solution of both as foliar spray. 
Total fresh weight of wheat variety BARI Gom 29 varied under drought stress as presented in Table 2. At 15 days after flowering, in control condition the total fresh weightplant ${ }^{-1}$ was $10.18 \mathrm{~g}$ and in drought condition it was 6.02g. Application of $\mathrm{Zn}$ and Fereduced the adverse effect of drought stress and the highest total fresh weightplant ${ }^{-1}(8.55 \mathrm{~g})$ was recorded in $\mathrm{Fe}_{3} \mathrm{SO}_{4} .7 \mathrm{H}_{2} \mathrm{O} @ 5 \%$ solution as foliar spray treatment, followed by $\mathrm{ZnSO}_{4} .7 \mathrm{H}_{2} \mathrm{O}+$ $\mathrm{Fe}_{3} \mathrm{SO}_{4} 7 \mathrm{H}_{2} \mathrm{O} @ 22 \mathrm{kgha}^{-1}$ of both $(7.45 \mathrm{~g}), \mathrm{ZnSO}_{4} \cdot 7 \mathrm{H}_{2} \mathrm{O} @ 5 \%$ solution as foliar spray, $(7.19 \mathrm{~g})$, $\mathrm{ZnSO}_{4} .7 \mathrm{H}_{2} \mathrm{O} @ 22 \mathrm{kgha}^{-1}(6.83 \mathrm{~g}), \mathrm{Fe}_{3} \mathrm{SO}_{4} .7 \mathrm{H}_{2} \mathrm{O} @ 22 \mathrm{kgha}^{-1}$, (6.77 g) and the lowest was recorded in $\mathrm{ZnSO}_{4} \cdot 7 \mathrm{H}_{2} \mathrm{O}+\mathrm{Fe}_{3} \mathrm{SO}_{4} .7 \mathrm{H}_{2} \mathrm{O} @ 5 \%$ solution of both as foliar spray (6.43g). Likewise, at 30 days after flowering, in control condition the total fresh weightplant ${ }^{-1}$ was $16.19 \mathrm{~g}$ and in drought condition it was $9.12 \mathrm{~g}$ and the highest total fresh weightplant ${ }^{-1}(12.13 \mathrm{~g})$ was recorded in $\mathrm{Fe}_{3} \mathrm{SO}_{4} 7 \mathrm{H}_{2} \mathrm{O} @ 5 \%$ solution as foliar spray treatment followed by $\mathrm{Fe}_{3} \mathrm{SO}_{4} .7 \mathrm{H}_{2} \mathrm{O} @ 22 \mathrm{kgha}^{-1}(10.69 \mathrm{~g}), \mathrm{Fe}_{3} \mathrm{SO}_{4} .7 \mathrm{H}_{2} \mathrm{O} @ 22 \mathrm{kgha}^{-1}(10.41 \mathrm{~g}), \mathrm{ZnSO}_{4} \cdot 7 \mathrm{H}_{2} \mathrm{O} @ 5 \%$ solution as foliar spray $(10.29 \mathrm{~g}), \mathrm{ZnSO}_{4} \cdot 7 \mathrm{H}_{2} \mathrm{O}+\mathrm{Fe}_{3} \mathrm{SO}_{4} .7 \mathrm{H}_{2} \mathrm{O} @ 22 \mathrm{kgha}^{-1}$ of both $(10.25 \mathrm{~g})$ and the lowest was recorded in $\mathrm{ZnSO}_{4} \cdot 7 \mathrm{H}_{2} \mathrm{O}+\mathrm{Fe}_{3} \mathrm{SO}_{4} .7 \mathrm{H}_{2} \mathrm{O} @ 5 \%$ solution of both as foliar spray $(9.90 \mathrm{~g})$. It was noticed that drought stress badly reduced total fresh weight in wheat and the application of micronutrients showed the positive effects to mitigate the drought stress in wheat. Zhang et al.(2011) reported that drought stress inhibited the growth of wheat seedlings, under drought stress, the root fresh weight was inhibited; reduction of water to promote root growth, and the root was relatively stout (Ma et al., 2012). Due to the lack of water, the aerial parts of slow growth, aboveground growth was inhibited, studies have shown that (Yuehua, 2013; Li and Ma, 2013), drought stress suppressed the dry matter accumulation in wheat seedling, so for plant height, root length, fresh weight, dry weight, etc. the trend were decreasing, but the effect of the $\mathrm{Zn}$ and $\mathrm{Fe}$ were found better in this experiment. Adequate $\mathrm{Zn}$ nutrition improves vegetative growth and drought tolerance in alfalfa by enhancing root growth and RWC (Grewal and Williams, 2000). The maintenance of good leaf water status is a result of proper control exerted by the guard cells in diverse conditions, which improves the growth and enhances crop survival under stress conditions (Steudle, 2002).

\section{Yield attributes}

Number of spikeplant ${ }^{-1}$ of wheat variety BARIGom 29 reduced significantly under drought stress as presented in Table 3. The number of spikeplant ${ }^{-1}$ was 3.42in control condition and in drought condition it was 1.39. Application of $\mathrm{Zn}$ and $\mathrm{Fe}$ had an influence to decrease the negative effect of drought stress and the highest number of spikeplant ${ }^{-1}$ (2.45) was recorded in $\mathrm{Fe}_{3} \mathrm{SO}_{4} .7 \mathrm{H} 2 \mathrm{O} @ 5 \%$ solution as foliar spray treatment, followed by $\mathrm{ZnSO}_{4} .7 \mathrm{H}_{2} \mathrm{O}+$ $\mathrm{Fe}_{3} \mathrm{SO}_{4} .7 \mathrm{H}_{2} \mathrm{O} @ 22 \mathrm{kgha}^{-1}$ of both(2.14), $\mathrm{Fe}_{3} \mathrm{SO}_{4} .7 \mathrm{H}_{2} \mathrm{O} @ 22 \mathrm{kgha}^{-1}(2.04), \mathrm{ZnSO}_{4} .7 \mathrm{H}_{2} \mathrm{O}+$ $\mathrm{Fe}_{3} \mathrm{SO}_{4} .7 \mathrm{H}_{2} \mathrm{O} @ 5 \%$ solution of both as foliar spray (2.03), $\mathrm{ZnSO}_{4} .7 \mathrm{H}_{2} \mathrm{O}$ @ $5 \%$ solution as foliar spray (1.89) and the lowest was recorded in $\mathrm{ZnSO}_{4} .7 \mathrm{H}_{2} \mathrm{O} @ 22$ kgha-1(1.76) under micronutrients treated condition.

Spike length of wheat variety BARI Gom 29 varied significantly under drought stress as presented in Table 3. The spike length was $10.80 \mathrm{~cm}$ in control condition and in drought condition it was found $9.01 \mathrm{~cm}$. Application of $\mathrm{Zn}$ and Fe tended to reduce the adverse effect of drought stress in most of the cases and the highest spike length $(10.72 \mathrm{~cm})$ was recorded in $\mathrm{Fe}_{3} \mathrm{SO}_{4} .7 \mathrm{H}_{2} \mathrm{O} @ 5 \%$ solution as foliar spray treatment followed by $\mathrm{ZnSO}_{4} .7 \mathrm{H}_{2} \mathrm{O} @ 5 \%$ solution as foliar spray $(10.18 \mathrm{~cm}), \quad \mathrm{Fe}_{3} \mathrm{SO}_{4} .7 \mathrm{H}_{2} \mathrm{O} @ 22 \quad \mathrm{kgha}^{-1}(10.12 \mathrm{~cm}), \quad \mathrm{ZnSO} \mathrm{CH}_{4} .7 \mathrm{H}_{2} \mathrm{O}+$ $\mathrm{Fe}_{3} \mathrm{SO}_{4} .7 \mathrm{H}_{2} \mathrm{O} @ 22 \mathrm{kgha}^{-1}$ of both $(9.87 \mathrm{~cm}), \mathrm{ZnSO}_{4} \cdot 7 \mathrm{H}_{2} \mathrm{O}+\mathrm{Fe}_{3} \mathrm{SO}_{4} .7 \mathrm{H}_{2} \mathrm{O} @ 5 \%$ solution of both as foliar spray $(9.82 \mathrm{~cm})$ and the lowest was recorded in $\mathrm{ZnSO}_{4} \cdot 7 \mathrm{H}_{2} \mathrm{O} @ 22 \mathrm{kgha}^{-}$ $1(9.75 \mathrm{~cm})$ under $\mathrm{Zn}$ and $\mathrm{Fe}$ applied condition. Spike length has important contribution to the final crop yield, it effects on the number of spikeletspike $e^{-1}$, grain size and number of 
grainsspike ${ }^{-1}$. More spike length leads to more number of spikelet spike ${ }^{-1}$ which leads to more number of grains and then ultimately the maximum crop yield. Sharafizad et al. (2013) reported that moderate dosage of salicylic acid $(1.2 \mathrm{mM})$ increased spike length.

Table 3. Effect of $\mathrm{Zn}$ and Fe micronutrients on yield and yield contributing characters of wheat under drought stress

\begin{tabular}{|c|c|c|c|c|c|}
\hline Treatments & $\begin{array}{c}\text { Number of } \\
\text { spikeplant }{ }^{-1}\end{array}$ & $\begin{array}{l}\text { Spike length } \\
\text { (cm) }\end{array}$ & $\begin{array}{l}\text { 100-grain } \\
\text { weight } \\
\text { (g) }\end{array}$ & $\begin{array}{c}\text { Grain } \\
\text { yieldplant } \\
\text { (g) }\end{array}$ & $\begin{array}{c}\text { Straw } \\
\text { yieldplant }{ }^{-1} \\
\text { (g) }\end{array}$ \\
\hline $\mathrm{C}$ & 3.42 & 10.80 & 5.41 & 35.89 & 20.20 \\
\hline $\mathrm{D}_{1}$ & 1.39 & 9.01 & 4.16 & 10.85 & 6.70 \\
\hline$D_{2}$ & 1.76 & 9.75 & 4.49 & 11.13 & 7.48 \\
\hline$D_{3}$ & 2.04 & 10.12 & 4.84 & 14.97 & 8.28 \\
\hline $\mathrm{D}_{4}$ & 2.14 & 9.87 & 4.92 & 11.30 & 6.97 \\
\hline$D_{5}$ & 1.89 & 10.18 & 4.68 & 15.06 & 8.48 \\
\hline $\mathrm{D}_{6}$ & 2.45 & 10.8 & 5.16 & 16.10 & 9.12 \\
\hline $\mathrm{D}_{7}$ & 2.03 & 9.82 & 4.35 & 11.29 & 7.57 \\
\hline LSD (5\%) & 0.96 & 0.72 & 0.59 & 5.91 & 3.02 \\
\hline CV (\%) & 26.9 & 4.2 & 7 & 21.8 & 18.8 \\
\hline
\end{tabular}

$\mathrm{C}=$ Control, $\mathrm{D}_{1}=$ Drought, $\mathrm{D}_{2}=$ Drought $+\mathrm{ZnSO}_{4} \cdot 7 \mathrm{H}_{2} \mathrm{O} @ 22 \mathrm{~kg} \mathrm{ha}{ }^{-1}, \mathrm{D}_{3}=$ Drought $+\mathrm{Fe}_{3} \mathrm{SO}_{4} 7 \mathrm{H}_{2} \mathrm{O} @ 22 \mathrm{kgha}$ 1, $\mathrm{D}_{4}=$ Drought $+\mathrm{ZnSO}_{4} \cdot 7 \mathrm{H}_{2} \mathrm{O}+\mathrm{Fe}_{3} \mathrm{SO}_{4} .7 \mathrm{H}_{2} \mathrm{O} @ 22 \mathrm{kgha}^{-1}$ of both, $\mathrm{D}_{5}=$ Drought $+\mathrm{ZnSO}_{4} \cdot 7 \mathrm{H}_{2} \mathrm{O} @ 5 \%$ solution as foliar spray, $\mathrm{D}_{6}=$ Drought $+\mathrm{Fe}_{3} \mathrm{SO}_{4} .7 \mathrm{H}_{2} \mathrm{O} @ 5 \%$ solution as foliar spray, $\mathrm{D}_{7}=$ Drought $+\mathrm{ZnSO}_{4} .7 \mathrm{H}_{2} \mathrm{O}+$ $\mathrm{Fe}_{3} \mathrm{SO}_{4} .7 \mathrm{H}_{2} \mathrm{O} @ 5 \%$ solution of both as foliar spray.

Individual grain weight is an important yield parameter that plays an important role in the actual yield of the crop. 100-grain weight of wheat variety BARI Gom 29 showed a variation due to drought stress as presented in Table 3 . In control condition the 100-grain weight was $5.41 \mathrm{~g}$ and in drought condition it was $4.16 \mathrm{~g}$. Under drought stress when $\mathrm{Zn}$ and Fe were applied, the highest 100 - grain weight $(5.16 \mathrm{~g})$ was recorded in $\mathrm{Fe}_{3} \mathrm{SO}_{4} 7 \mathrm{H}_{2} \mathrm{O} @ 5 \%$ solution as foliar spray treatment followed by $\mathrm{ZnSO}_{4} \cdot 7 \mathrm{H}_{2} \mathrm{O}+\mathrm{Fe}_{3} \mathrm{SO}_{4} 7 \mathrm{H}_{2} \mathrm{O} @ 22 \mathrm{kgha}-1$ of both $(4.92 \mathrm{~g}), \mathrm{Fe}_{3} \mathrm{SO}_{4} .7 \mathrm{H}_{2} \mathrm{O}$ @ $22 \mathrm{kgha}^{-1}(4.84 \mathrm{~g}), \mathrm{ZnSO}_{4} .7 \mathrm{H}_{2} \mathrm{O} @ 5 \%$ solution as foliar spray $(4.68 \mathrm{~g}), \mathrm{ZnSO}_{4} .7 \mathrm{H}_{2} \mathrm{O} @ 22$ $\mathrm{kgha}^{-1}(4.49 \mathrm{~g})$ and the lowest was recorded in $\mathrm{ZnSO}_{4} \cdot 7 \mathrm{H}_{2} \mathrm{O}+\mathrm{Fe}_{3} \mathrm{SO}_{4} .7 \mathrm{H}_{2} \mathrm{O} @ 5 \%$ solution of both as foliar spray (4.35g).Monjezi et al. (2013) proposed that zinc spray alleviates drought stress effect on thousand grain weight in wheat. Treated wheat plants with SA or Zn resulted in significant increases in the number of tillers and spikesplant ${ }^{-1}$ as well as of grainsplant ${ }^{-1}$ and weight of grains when irrigated water every 14 and 28 days reported by Mahmoud (2015).

Grain yieldplant ${ }^{-1}$ of wheat variety BARI Gom 29 varied widely under drought stress as presented in Table 3. In control condition the grain yieldplant ${ }^{-1}$ was $35.89 \mathrm{~g}$ and in drought conditions it was $10.85 \mathrm{~g}$. and under drought condition the highest grain yieldplant ${ }^{-1}(16.10 \mathrm{~g})$ was recorded when $\mathrm{Fe}_{3} \mathrm{SO}_{4} .7 \mathrm{H}_{2} \mathrm{O} @ 5 \%$ solution was applied as foliar spray followed by $\mathrm{ZnSO}_{4} .7 \mathrm{H}_{2} \mathrm{O} @ 5 \%$ solution as foliar spray (15.06 g), $\mathrm{Fe}_{3} \mathrm{SO}_{4} 7 \mathrm{H}_{2} \mathrm{O} @ 22 \mathrm{~kg} \mathrm{ha}^{-1}(14.97 \mathrm{~g})$, $\mathrm{ZnSO}_{4} \cdot 7 \mathrm{H}_{2} \mathrm{O}+\mathrm{Fe}_{3} \mathrm{SO}_{4} \cdot 7 \mathrm{H}_{2} \mathrm{O} @ 22 \mathrm{~kg} \mathrm{ha}{ }^{-1}$ of both $(11.30 \mathrm{~g}), \mathrm{ZnSO}_{4} \cdot 7 \mathrm{H}_{2} \mathrm{O}+\mathrm{Fe}_{3} \mathrm{SO}_{4} .7 \mathrm{H}_{2} \mathrm{O} @$ $5 \%$ solution of both as foliar spray $(11.29 \mathrm{~g})$ and the lowest was recorded in $\mathrm{ZnSO}_{4} \cdot 7 \mathrm{H}_{2} \mathrm{O} @ 22$ $\mathrm{kgha}^{-1}(11.13 \mathrm{~g})$. These findings are in agreement with the results of Monjezi et al. (2013) who recorded the highest seed yield from the simultaneous application of iron and zinc, under the stress-free condition and application of iron under the stress-free condition were 660.79 and $651.67 \mathrm{gm}^{-2}$, respectively. Drought stress at any particular stage or during entire growing season considerably reduced the yield and components of yield in wheat crop (Nasri, 2005). Raza et al. (2012) found maximum reduction in grain yield plant ${ }^{-1}$ (48.45\%)when drought 
occurred at grain filling stage, whereas about $10.45 \%$ and $25.15 \%$ in grain yield plant ${ }^{-1}$ was noticed when drought occurred at tillering and anthesis stage of wheat, respectively. Maleki et al. (2014) stated that, zinc sulfate can decrease negative effects of drought stress on maize grain yield and yield components

Straw yieldplant ${ }^{-1}$ of wheat variety BARIGom 29 varied appreciably under drought stress as presented in Table 3. In control condition the straw yieldplant ${ }^{-1}$ was $20.20 \mathrm{~g}$ and in drought condition it was $6.70 \mathrm{~g}$. Application of $\mathrm{Zn}$ and Fe tended to alleviate the detrimental effect of drought stress in most of the cases and the highest straw yieldplant ${ }^{-1}(9.12 \mathrm{~g})$ was recorded in $\mathrm{Fe}_{3} \mathrm{SO}_{4} .7 \mathrm{H}_{2} \mathrm{O} @ 5 \%$ solution as foliar spray treatment followed by $\mathrm{ZnSO}_{4} \cdot 7 \mathrm{H}_{2} \mathrm{O} @ 5 \%$ solution as foliar spray (8.48g), $\mathrm{Fe}_{3} \mathrm{SO}_{4} .7 \mathrm{H}_{2} \mathrm{O} @ 22 \mathrm{kgha}^{-1}(8.28 \mathrm{~g}), \mathrm{ZnSO}_{4} \cdot 7 \mathrm{H}_{2} \mathrm{O}+\mathrm{Fe}_{3} \mathrm{SO}_{4} .7 \mathrm{H}_{2} \mathrm{O} @ 5 \%$ solution of both as foliar spray $(7.57 \mathrm{~g}) \mathrm{D}_{2}(7.48 \mathrm{~g})$ and the lowest was recorded in $\mathrm{ZnSO}_{4} .7 \mathrm{H}_{2} \mathrm{O}+\mathrm{Fe}_{3} \mathrm{SO}_{4} .7 \mathrm{H}_{2} \mathrm{O} @ 22 \mathrm{kgha}^{-1}$ of both (6.97g). Withholding water after anthesis reduced straw yield by $28.5 \%$ as claimed by Johari-Pireivatlou (2010). Shirazi et al. (2014) found that different irrigation regimes had significant effect on the straw yield. Straw yield exhibited the tendency of increasing with the increase of irrigation levels. This might be due to the luxuriant vegetative growth in terms of plant height and numbers of tillerplant ${ }^{-1}$. Zn application results in appreciable increase in leaf area, the content of chlorophyll and other photosynthetic pigments, and stomatal conductance, thus resulting in improved growth and yield (Karim et al., 2012). Similarly, Sultana et al. (2016) noted that Zn countered the adverse impact of drought and remarkably increased wheat productivity. In another study, Chattha et al. (2017) noted that $\mathrm{Zn}$ application improved maize yield and harvest index in drought stress. Moreover, Hera et al. (2018) noted that foliar applied $\mathrm{Zn}$ diminished the negative impacts of water deficit and increased growth and yield of wheat. Seadh et al. (2009) reported that the mixture of four micronutrients $(\mathrm{Cu}, \mathrm{Mn}, \mathrm{Fe}$ and $\mathrm{Zn}$ ) at the rate of $500 \mathrm{ppm}$ produced the highest values of grain and straw yields with the micronutrient foliar application treatments in wheat.

\section{Conclusion}

Water deficit stress negatively affects the plant height, fresh weight of leaf, stem and root as well as yield of wheat. Application of $\mathrm{Fe}$ and $\mathrm{Zn}$ micronutrients reduced the adverse effects of drought stress and improved these parameters of wheat under drought condition. Among the micronutrients, $\mathrm{Fe}\left(\mathrm{Fe}_{3} \mathrm{SO}_{4} .7 \mathrm{H}_{2} \mathrm{O}\right)$ was found more effective when it was applied as foliar spray @ $5 \%$ solution for increasing the growth and yield of wheat in water deficit condition.

Acknowledgement: The authors are grateful to Ministry of Science and Technology, Government of Bangladesh for funding the research.

\section{References}

Abbas, G., M.Q. Khan, M.J. Khan, F. Hussain and I. Hussain. 2009. Effect of iron on the growth and yield contributing parameters of wheat (Triticum aestivum L.). The J. of Animal \& Plant Sci. 19(3): 135-139.

Arnon, I. 1972. Crop Production in Dry Regions. Vol. I: Background and Principles, London: Leonard Hill (1972), p.650.

BARC (Bangladesh Agricultural Research Council). 2012. Fertilizer Recommendation Guide. Bangladesh Agricultural Research Council. Farmgate, Dhaka. 
Bayoumi, T.Y., M.H. Eid and E.M. Metwali. 2008. Application of physiological and biochemical indices as a screening technique for drought tolerance in wheat genotypes. Afr. J. Biotech. 7(14): 1684-5315.

Chattha, M.U., M.U. Hassan, I. Khan, M.B. Chattha, A.Mahmood, M.U. Chattha, M. Nawaz, M.N. Subhani, M. Kharal and S. Khan. 2017. Biofortification of Wheat Cultivars to Combat Zinc Deficiency. Front. Plant Sci.8: 281.[CrossRef] [PubMed.

Gomez, A.A. and A.A. Gomez. 1984. Statistical Procedure of Agricultural Research. John Wiley and Sons. New York. 20-2015.

Grewal, H.S. and R. Williams. 2000. Zinc nutrition affects alfalfa responses to water stress and excessive moisture. J. Plant Nutri.23: 949-962. [CrossRef].

Hera, M.H.R.., M. Hossain and A.K. Paul. 2018. Effect of foliar zinc spray on growth and yield of heat tolerant wheat under water stress. Int. J. Biol. Environ. Eng.1: 10-16.

Johari-Pireivatlou, M. 2010. Effect of soil water stress on yield and proline content of four wheat lines. Afr. J. Biotech. 9(1): 1684-5315.

Kamal, A.H.M., K.H. Kim, K.H. Shin, J.S. Choi, B.K. Baik, H. Tsujimoto and S.H. Woo. 2010. Abiotic stress responsive proteins of wheat grain determined using proteomics technique. Aus. J. Crop Sci. 4(3): 196- 203.

Karim, M., Y.Q. Zhang, R.R. Zhao, X.P. Chen, F.S. Zhang and C.Q. Zou. 2012. Alleviation of drought stress in winter wheat by late foliar application of zinc, boron, and manganese. J. Plant Nutr. Soil Sci.175: 142-151.[CrossRef].

Li, M. and J.L. Ma. 2013. Influences of salt and drought stress on proline content in three popular varieties. Hunan Agric. Sci. 1(110): 105-107.

Ma, F., D.D. Li, J. Cai, D. Jiang, W.X. Cao and T.B. Dai. 2012. Responses of wheat seedlings root growth and leaf photosynthesis to drought stress. Chinese J. Appl. Ecol. 23(3): 724-730.

Mahmoud, R.S. 2015. Application of salicylic acid and zinc improves wheat yield through physiological processes under different levels of irrigation intervals. Int. J. Plant Res. 5(5): 136-156.

Maleki, A., S. Fazel, R. Naseri, K. Rezaei and M. Heydari. 2014. The effect of potassium and zinc sulfate application on grain yield of maize under drought stress conditions. Adv. Environ. Biol. 890-894.

Manivannan, P., C.A. Jaleel, B. Sankar, A. Kishorekumar, R. Somasundaram, G.A. Lakshmanan and R. Panneerselvam. 2007. Growth, biochemical modifications and proline metabolism in Helianthus annuus L. as induced by drought stress. Colloids and Surfaces B: Biointerfaces: 59(2): 141-149.

Monjezi, F., F. Vazin and M. Hassanzadehdelouei. 2013. Effects of iron and zinc spray on yield and yield components of wheat (Triticum aestivum L.) in drought stress. Cercetari agronomice in Moldova. 46(1): 23-32.

Morizet T., M. Pollucsck and D. Togola. 1983. Drought tolerance in four maize varieties. Int. J. Bot. Studies. 4(6): 43-50.

Nasri, M. 2005. Interaction of nutrient elements and drought stress in cultivars of Brassica napus. In The second international conference on integrated approaches to sustain and improve plant production under drought stress. Rome, Italy, September. 109: 24-28.

Nazar, R., N. Iqbal, A. Masood, M.I.R. Khan, S. Syeed and N.A. Khan. 2012. Cadmium toxicity in plants and role of mineral nutrients in its alleviation. American J. Plant Sci. 3(10): 241-624.

Raza, S., M.F., Saleem, I.H., Khan, M.Jamil, M., Ijaz and M.A. Khan. 2012. Evaluating the drought stress tolerance efficiency of wheat (Triticum aestivum L.) cultivars. Russian J. Agric. SocioEconomic Sci. 12(12): 41-47. 
Salsinha, Y.C.F., D. Indradewa, Y. Asih Purwestri and D. Rachmawati. 2019. Morphophysiologica lchanges during vegetative stage drought stress in the local pigmented rice (Oryza sativa L.) from east nusatenggar. The 6th International Conference on Biological Science ICBS, AIP Conf. Proc. 2260, 030020-1-030020-9; https://doi.org/10.1063/5.0015865Published by AIP Publishing. 978-0-7354-2020-5/ $\$ 30.00$.

Saxena, I. and G.S. Shekhawat.2013. Nitric oxide (NO) in alleviation of heavy metal induced phytotoxicity and its role in protein nitration. Nitric Oxide. 32: 13-20.

Seadh, S.E., M.I. El-Abady, A.M. El-Ghamryand S. Farouk. 2009. Influence of micronutrients foliar application and nitrogen fertilization on wheat yield and quality of grain and seed. J.Biol. Sci.9(8): 851-858.

Shahbaz, M., Y. Masood, S. Perveen and M. Ashraf. 2012. Is foliar-applied glycinebetaine effective in mitigating the adverse effects of drought stress on wheat (Triticum aestivum L.).J. Appl. Bot. Food Quality. 84(2): 192.

Sharafizad, M., A. Naderi, S.A.Siadat, T. Sakinejad and S. Lak. 2013. Effect of drought stress and salicylic acid treatment on grain yield, process of grain growth, and some of chemical and morphological traits of Chamran cultivar wheat (Triticumaestivum). Adv. Environ. Biol. 7(11): 3234-3241.

Shirazi M.U, M.A. Khan, N. Bhatti, A. Unar, A.H.B. Bozdar, S.M. Mujtaba and M.I. Lashari. 2014. Growth and Water use efficiency in wheat genotypes grown under water stress condition. J. Agric. Res. Develop. 4: 023-028.

Steudle, E. 2002. Water uptake by roots: Effects of water deficit.J. Exp. Bot.51: 1531-1542. [CrossRef][PubMed].

Sultana, S., H.M. Naser, N.C. Shil, S.Akhter and R.A. Begum. 2016. Effect of foliar application of zinc on yield of wheat grown by avoiding irrigation at different growth stages. Bangladesh J. Agric. Res.41: 323-334.[CrossRef].

Tabatabai, S.M.R., M. Oveysi and R. Honarnejad. 2015. Evaluation of some characteristics of corn under water stress and zinc foliar application. Adv. Environ. Biol. 16: 34-38.

Tripathi, D.K., G. Bashri, S. Shweta, P. Ahmad and V. Singh. 2017. Efficacy of silicon against aluminum toxicity in plants: an overview. Silicon in Plants: Adv. Future Prospects. 1: 355366.

Wang, W. X., T. Barak, B. Vinocur, O. Shoseyov and A. Altman. 2003. Abiotic resistance and chaperones: possible physiological role of SP1, a stable and stabilizing protein from Populus. In: Plant Biotech. 2002 and Beyond. 439-443.

Yuehua, S.M. 2013. Effect of Drought Stress Simulated by PEG-6000 on Physiological Character of Syneilesis Aconitifolia.

Zhang, Y.Q., Q. Lin, J.B. Liu, H.S. Zhang and C.X. Zhao. 2011. Effects of drought stress on photosynthetic characteristics and yield of different fertilizer and water types of wheat. J. Tritic. Crops. 31(4): 724-730. 